Splint or plaster cylinder for first patellar dislocation

Report by Martin Thomas, Research Fellow

Search checked by Paul Wallman, Specialist Registrar

Clinical scenario

A 20 year old woman presents to the emergency department having suffered her first lateral patellar dislocation one hour before. She has managed to reduce it herself. You know that surgery offers no advantage over conservative management, but wonder what is the best approach to initial immobilisation.

Three part question

In [patients with primary patellar dislocation] is [a plaster cylinder, a posterior (cricket pad) splint or bandaging] better at [reducing symptoms and preventing redislocation]?

Search strategy

Medline 1966 to $6 / 99$ using the OVID interface. ( exp patella OR patella\$.mp $\}$ AND \{exp dislocations OR dislocate\$.mp OR dislocation \$.mp \}) AND \{exp emergency treatment OR exp treatment failure $O R$ exp treatment outcome OR treatment\$.mp \} AND maximally sensitive RCT filter LIMIT to human and english.

\section{Search outcome}

Seventy nine papers were found of which 75 were irrelevant and three of insufficient quality for inclusion. The remaining paper is shown in table 5 .

\section{Comment}

The best evidence in this area is weak. Bandaging and bracing seem to give the worst outcome, while there is no significant difference in redislocation rate between plaster and posterior (cricket pad) splinting. The better range of movement found after posterior splinting suggest this is the best treatment overall. A well designed randomised controlled trial is required to further investigate this question.

\section{Clinical bottom line}

Posterior (cricket pad) splinting offers the best overall outcome after primary patellar dislocation.

1 Maenpaa H, Lehto MUK. Patellar dislocation. The long-term results of non-operative management in 100 patients. Am 7 Sports Med 1997;25:213-17.

The BMA library supplied the papers.

Table 5

\begin{tabular}{|c|c|c|c|c|c|}
\hline $\begin{array}{l}\text { Author, date, and } \\
\text { country }\end{array}$ & Patient group & $\begin{array}{l}\text { Study type (level } \\
\text { of evidence) }\end{array}$ & Outcomes & Key results & Study weaknesses \\
\hline $\begin{array}{l}\text { Maenpaa and Lehto, } \\
\text { Finland, } 1997^{1}\end{array}$ & $\begin{array}{l}100 \text { patients with primary } \\
\text { patella dislocation } \\
\text { Plaster cylinder }(60) v \\
\text { posterior splint }(17) v \\
\text { bandage and brace }(23)\end{array}$ & $\begin{array}{l}\text { Retrospective } \\
\text { cohort }\end{array}$ & $\begin{array}{l}\text { Redislocation } \\
\text { incidence } \\
\text { Late problems } \\
\text { Range of } \\
\text { movement }\end{array}$ & $\begin{array}{l}\text { Significantly higher } \\
(p<0.05) \text { in bandage } \\
\text { group } \\
\text { No significant difference } \\
\text { Significantly better } \\
\quad(p<0.05) \text { in posterior } \\
\text { splint group }\end{array}$ & $\begin{array}{l}\text { Not randomised } \\
\text { Immobilisation times vary between } \\
\text { groups } \\
\text { Small numbers in splint and } \\
\text { bandage groups }\end{array}$ \\
\hline
\end{tabular}

